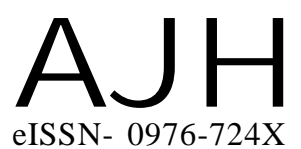

Received : 07.05.2014

Accepted : 22.11.2014

Members of the Research Forum

Associated Authors:

Department of Horticulture, Dr.

Panjabrao Deshmukh Krishi

Vidyapeeth, AKOLA(M.S.) INDIA

Author for correspondence :

AJIT K. SAHOO

Department of Horticulture, Dr.

Panjabrao Deshmukh Krishi

Vidyapeeth, AKOLA(M.S.) INDIA

Email : peterson2702@gmail.com
THE ASIAN JOURNAL OF HORTICULTURE

Volume 9 | Issue 2 | Dec., $2014 \mid$ 500-502

Visit us -www.researchjournal.co.in

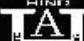

$\mathrm{S}$

A CASE STUDY

DOI : 10.15740/HAS/TAJH/9.2/500-502

\section{Effect of drying methods on quality of banana powder}

\section{AJIT K. SAHOO, ARVIND M. SONKAMBLE ${ }^{1}$ AND SURENDRA R. PATIL ${ }^{1}$}

ABSTRACT : An experimental study was performed to determine the drying characteristics of banana powder in solar drying and cabinet drying. Cultivar Basrai banana powder was prepared from mature unripe fruits collected from local market of Akola, Maharashtra. The physicochemical observations like moisture, $\mathrm{pH}$, TSS, titrable acidity, ascorbic acid, reducing sugar, total sugar and non-reducing sugar of the flour were recorded and the data obtained were analyzed using FCRD model. Solar dried banana powder recorded higher $\mathrm{pH}$, ascorbic acid, total sugar and TSS but lower in moisture and titrable acidity at $120^{\text {th }}$ day of storage which is good for keeping quality (storage).

KEY WORDS : Banana, Cabinet drying, Solar drying, Physicochemical observation, Powder

HOW TO CITE THIS ARTICLE : Sahoo, Ajit K., Sonkamble, Arvind M. and Patil, Surendra R. (2014). Effect of drying methods on quality of banana powder. Asian J. Hort., 9(2) : 500-502. 